\title{
A Tale of Two Tragedies - A plea for open standards
}

\author{
Maurits Dolmans $^{a}$ \\ (a) Lawyer, Cleary Gottlieb Steen \& Hamilton LLP, London \\ and Brussels offices, Rotterdam, New York and Brussels Bars
}

With an introduction by Carlo Piana ${ }^{b}$

(b) Lawyer, Array, Milan, Italy, member of the Editorial

Committee of IFOSS l. rev.

DOI: $\underline{10.5033 / \text { ifosslr.v2i2.46 }}$

\begin{abstract}
The IT sector is characterized by two market failures, the "tragedy of the commons" and the "tragedy of the anti-commons", both of which must be resolved if IT innovation is to flourish and lock-in avoided. This involves a careful balancing of IPR protection and standardsetting, while avoiding hold-up and preserving opportunities for the significant innovation provided by the open source movement. The Author examines the shortcomings of the present system from a European Law perspective and expresses a plea for Open Standards in the interest of innovation and technological progress. As IT progresses, more and more products are compound items, incorporating technology co-owned by many different patent holders, co-manufactured by different producers, and interoperating with other complex products. A hold-up by a non-practicing entity or a rival using a single patent on a single component can kill an entire product. This article explores the criteria for "open standards", and explains why royalty-free licensing of interoperability standards is appropriate in the software area (since RF standards can be implemented in both open source and proprietary software, thus allowing both models to compete on quality and functionality), while FRAND licensing is necessary for telecommunications. The notion of FRAND terms is further explored from a legal and economic perspective, explaining ways to determine fair pricing, and the need to ensure nondiscriminatory terms in order to preserve competition in products implementing the standard. The article concludes with some comments on an interesting report by RAND Europe on "Trends in Connectivity Technologies and their Socio-Economic Impacts Policy Options for the Ubiquitous Internet Society".
\end{abstract}




\section{Keywords}

Law; Information Technology; telecommunications, Interoperability;

Open Standards, Standard Setting, FRAND, RAND; Patents, hold-up.

\section{Info}

This item is part of the Articles section of IFOSS L. Rev. For more information, please consult the relevant section policies statement.

This article has been independently peer-reviewed.

\section{Introduction By Carlo Piana}

The article provides a very good explanation of why the interconnection between standardization and patents need a serious overhaul in order to address the concerns of competition failure in both the software and the general IT market, in the direction of what we call "Open Standards."

On behalf of the Editorial Committee, I would like to profoundly thank the Review "Concurrences", where the article first appeared, for very kindly allowing republication of the same on our review. It is our policy to republish non-original works only in a few cases, when the relevance of the matter, the quality of the writing and of the analysis justify so; and when the first publication was on a review which has a separate readership from ours. Maurits Dolmans's article matched both requirements and brings a very valuable contribution to the discussion.

Maurits is a fine lawyer, a rigorous writer and an expert in the field. I have had the pleasure to work with him in a number of cases, first and foremost the seminal case Microsoft. ${ }^{2}$ In this writing he analyzes the interaction between standard and patents, how the current IPR policies of the standards setting organization often fall short of delivering a truly open and independent standard. Conversely, the current practices, the intertwined and interdependency of modern IT and the nature of patents create more often than not inextricable "patent thickets" which serve no other purpose than extort unjustified royalties through questionable practices, under the common name of "patent hold-up." I could not agree more.

The Author also analyzes remarkably well how - too frequently - RAND terms imply an actual discrimination against Free and Open Source Software implementations. Again, this is consistent with my experience, especially as a lawyer assisting clients in technology transfer agreements, mainly in the multimedia field.

Maurits adopts a position that clearly favors Open Standard without any ideological bias. He has a background that is very different from mine and those who are most likely to write on this Review. He finds for the case of Open Standards on a purely legal and technical point of view, out of a long and intensive experience on what RAND means in practical terms. Not ideology, indeed, but only simple and pertinent motives drive those who favor competition and technological advancement over hyper-exploitation of proprietary rights and an idolization of "Intellectual Property."

1 Concurrences $\mathrm{N}^{\circ} 12010, \mathrm{n}^{\circ} 30204$, pp. 1338 http://www.concurrences.com

2 Case T-201/04 Microsoft v Commission [2007] ECR II-3601 


\section{A Tale of Two Tragedies - A plea for open standards, and some comments on the RAND report}

As early 1992, the European Commission published a Communication on Intellectual Property Rights ("IPRs") and Standardization, requiring open access to European standards on irrevocable, fair, reasonable, and non-discriminatory ("FRAND”) terms. ${ }^{3}$ In 1999, an ETSI working group discussing a definition of FRAND for 3G mobile communications concluded that the Maximum Cumulative Royalty Rate "should be set in single figures". The 2001 Guidelines for Horizontal Agreements require that "an appreciable proportion of the industry is involved in the setting of the standard in a transparent manner," that "the necessary information to apply the standard must be available to those wishing to enter the market," and that "access to the standard must be possible for third parties on fair, reasonable and non-discriminatory terms." To summarize it all, Commissioner Kroes stated recently that "Interoperability encourages competition on the merits between technologies from different companies, and helps prevent lock-in. Standards are the foundation of interoperability." She added that rates must be fair, and "based on the inherent value of the interoperability information (rather than the information's value as a gatekeeper)." She concluded: "choosing open standards is a very smart business decision indeed."

In this light, it is surprising that there is so much disagreement on the definition of open standards and on the conditions for licensing essential IPRs. These questions are quite contentious as

3 EC Commission, Communication on IPRs and Standardization, COM(1992) 445, section 6.2 (General Principles), available at http://aei.pitt.edu/1222/http://aei.pitt.edu/1222/ .

4 Report by the UMTS IPR Working Group, "Third Generation Mobile Communications: The Way Forward for IPR", January 1999, available at http://www.3gpp.org/ftp/PCG/PCG_01/Docs/PCG1_11.pdfhttp://www.3gpp.org/ftp/PCG/PCG_01/Docs/PCG1_11.pdf . See also Ericsson's Comments on the European Commission's White Paper on ICT Standardisation, available at http://ec.europa.eu/enterprise/sectors/ict/files/consultation_standardisation_2009/128_ericsson_en.pdfhttp://ec.europa.e u/enterprise/sectors/ict/files/consultation_standardisation 2009/128 ericsson en.pdf .

5 European Commission Notice - Guidelines on the applicability of Article 81 [now Article 101 TFUE] to horizontal cooperation agreements, OJ C3, January 6, 2001, at 25, para. 169 (2001) ("Guidelines on Horizontal Agreements"). These were updated in 2010 by the Guidelines on the applicability of Article 101TFEU to horizontal co-operation agreements, OJ C11/1, January 14, 2011, at 1. See especially the sections on standardsetting agreements, para. $257 \mathrm{ff}$.

6 Guidelines on Horizontal Agreements, above, para. 169.

7 N. Kroes, SPEECH/08/317, "Being open about standards", Speech to Open Forum Europe, Brussels, June 10, 2008, (“OFE Speech"). See also Commissioner Kroes, SPEECH/09/475 "Setting the Standards High", October 15, 2009. Interoperability is defined in the CFI Judgment in Microsoft (see below), para. 225 and following: "interoperability between two software products means the capacity for them to exchange information and to use that information mutually in order to allow each of those software products to function in all the ways envisaged." This case concerned client-to-server and server-to-server communication, i.e., communication between two separate computer systems from different vendors in a network. See also para. 237: "the attainment of that objective assumes that non-Microsoft work group server operating systems are capable of receiving a specific message from a Windows client PC or work group server operating system and giving the required response to that message on the same conditions as a Windows work group server operating system and also of enabling Windows client PC or work group server operating systems to react to that response just as though it came from a Windows work group server operating system." "Interoperability" between two computer systems should be distinguished from "compatibility" (whether a software or hardware component of a computer system can be substituted by another component without modification) and "portability" (whether a software or hardware component of a computer system or piece of software can be modified or adjusted to become part of another computer system). The Microsoft judgment did not cover those notions. 
indicated by a series of recent debates and cases (such EIF, ${ }^{8}$ Microsoft, ${ }^{9}$ Rambus, ${ }^{10}$ Qualcomm, ${ }^{11}$ IPCom, ${ }^{12}$ and the 2011 Guidelines on Horizontal Agreements ${ }^{13}$ ). The debate is on occasion conducted with fundamentalist fervor, pitching proponents of unlimited IPRs on one side of the spectrum against the open source community on the other. It is useful, therefore, to analyze the debate from a coolly rational policy perspective, and ask whether the rules could not be adjusted to accommodate different situations in different industry sectors.

At the root of the problem is a conflict between measures to resolve two different market failures: the "tragedy of the commons" and the "tragedy of the anti-commons".

We all know the "tragedy of the commons", the overuse of public goods controlled by no one. In the 18th Century, it was found that common land in Britain was overexploited, because each user had an individual interest in letting the maximum number of cattle freely graze on it, with the result that the fields were exhausted, and everyone suffered..$^{14}$ Even today, we poison ourselves or even risk changing our climate, because we produce goods the price of which does not include the cost imposed on society caused by the pollution of "free" air, soil and water (a "price externality"). Private restraints or public regulation may be needed to solve this market failure. Similar thinking led to the adoption of intellectual property laws. Innovators invest and sink funds in the creation of ideas and their expression. If all ideas were free and we all enjoyed full freedom to copy expression, imitators could enter the market without limitation, free riding on the innovators' investments. To allow creators to raise price above marginal costs for a while and thus recover sunk R\&D costs and be compensated for risk, IPRs exclude competition from imitators for some

8 European Interoperability Framework, available at http://ec.europa.eu/isa/strategy/doc/annex ii_eif_en.pdf and http://ec.europa.eu/isa/strategy/index en.htm. . For a comment, see Mark Bohannon, "European Interoperability Framework Supports opened, December 17, 2010, available at http://opensource.com/government/10/12/europeaninteroperability-framework-supports-openness.

9 Case T-201/04 Microsoft v Commission [2007] ECR II-3601, and Microsoft Interoperability Undertaking, December 16,2009 , available at

http://www.microsoft.com/presspass/presskits/eumsft/docs/MicrosoftInteroperabilityUndertaking16Dec2009.dochttp:// www.microsoft.com/presspass/presskits/eumsft/docs/MicrosoftInteroperabilityUndertaking16Dec2009.doc . For ongoing debate on Microsoft's activities in connection OOXML standard setting, see entries in Rob Weir's blog, An Antic Disposition, available at http://www.robweir.com/blog/http://www.robweir.com/blog/, especially "The Final OOXML Update", parts I, II and III.

10 European Commission, Notice art. 27(4) Reg. 1/2003, Rambus, case COMP/38636, OJ C133, June 12, 2009, p.16; Rambus Article 9 Reg. 1/2003, commitments, available at

http://ec.europa.eu/competition/antitrust/cases/decisions/38636/commitments.pdf; See also press release IP/09/1897, December 9, 2009, and Commissioner Kroes, SPEECH/09/575, "Lessons learned for standardization".

11 Broadcom Corp. v. Qualcomm Inc., 501 F.3d 297, 310 (3d Cir. 2007) ("Deception in a consensus-driven private standard-setting environment harms the competitive process by obscuring the costs of including proprietary technology in a standard and increasing the likelihood that patent rights will confer monopoly power on the patent holder[...] Deceptive FRAND commitments, no less than deceptive nondisclosure of IPRs, may result in such harm"); See also Japan FTC Cease and Desist Order Against Qualcomm, September 20, 2009 (on appeal) available at http://www.jftc.go.jp/e-page/pressreleases/2009/September/090930.pdfhttp://www.jftc.go.jp/epage/pressreleases/2009/September/090930.pdf , Korean FTC Press Release "KFTC took corrective measures against Qualcomm for abusing its monopoly market status in modem chip market; Imposition of fine and issuance of corrective order for discriminative royalty rates, conditional rebates, etc", July 23, 2009; "EC closes formal proceedings against Qualcomm", MEMO/09/516 of November 24, 2009.

12 European Commission, MEMO/09/549, December 12, 2009 on IPCom's public statement confirming its FRAND Declaration, and IPCom statement http://www.ipcom-munich.com/IPCom_Frand_Declaration.pdfhttp://www.ipcommunich.com/IPCom_Frand_Declaration.pdf.

13 European Commission Notice - Guidelines on the applicability of Article 101TFEU to horizontal co-operation agreements, OJ C11/1, January 14, 2011, at 1, para. 257ff.

14 G. Hardin, "The Tragedy of the Commons", Science, Vol. 162, No. 3859 (December 13, 1968), p. 1243-1248 
time, subject to conditions. Thus, patent law "secures to the inventor, for a limited time, the exclusive use of his invention; and thereby adds the fuel of interest to the fire of genius." 15

Less well known is the opposite phenomenon, the "tragedy of the anti-commons." This is the under-use of private goods that are controlled by more than one rightholder. Michael Heller in his fascinating Gridlock Economy mentions a series of arresting examples. ${ }^{16}$ Just a few: the banks of the Rhine are dotted with a sequence of picturesque robber baron castles, each of whom raised tolls on Rhine river traffic, with the result that no one used the river and no one received toll revenues. Google Book Search is being blocked by a multiplicity of rightholders in Europe, with the foreseeable outcome that orphan works remain dead, neither Google nor the European rightholders or libraries will make any money, and readers are deprived of access. And with every 3G cell phone being covered by thousands of patent families, each essential patent owner can block every other one, which the risk that no technology owner can use its technology without striking a compromise with the others. ${ }^{17}$

This is where standards and open source come in. As IT progresses, more and more products are compound items, made of many components incorporating technology co-owned by many different patent holders, manufactured by a series of different producers, and interoperating with other complex products. The computer and the mobile phone are perfect examples. They are multipart combinations of software, processors, modems, and electrical components, and are in turn part of networks that include other complex products (servers, base stations, routers, switches, servers and related network products). If each component manufacturer chose its preferred technology, these products could not interoperate in a network and no one could compete (or in exceptional cases, a manufacturer could gradually monopolize all key products in a closed network, chilling innovation ${ }^{18}$ ).

By compromising and selecting a common standard, producers are able to break the logjam. If they are truly open, standards allow "best of breed" components from different manufacturers to be combined, with maximum efficiency. Creating a standard, however, raises the risk of a tragedy of anti-commons at a higher level: patent "hold-up". Once an industry has agreed to a standard, and especially after producers have implemented it, industry becomes "locked in". ${ }^{19}$ This is an

15 A. Lincoln, "Lecture on Discoveries and Inventions", in Collected Works of Abraham Lincoln (R. Basler, ed., 1953) (1858). An alternative to using IPRs would be for government, academia, or charitable institutions to fund R\&D, or to look for alternative revenue opportunities such as services-funded or advertising-funded R\&D.

16 M. Heller, The Gridlock Economy - How Too Much ownership Wrecks Markets, Stops Innovation, and Costs Lives, Basic Books, 2008.

17 This, too, is not a new concept. In economics, this is called a problem of "Cournot complements", named after the 19th century French economist who discovered that monopolist producers of complementary products may both block each other to extract monopoly rents, thus reducing output below the level that a single monopolist would have produced. See M. Lemley and C. Shapiro, "Patent Holdup and Royalty Stacking," (2007) Texas Law Review, Vol. 85:1991-2049, at

http://faculty.haas.berkeley.edu/SHAPIRO/stacking.pdfhttp://faculty.haas.berkeley.edu/SHAPIRO/stacking.pdf , and C. Shapiro, "Navigating the Patent Thicket: Cross Licenses, Patent Pools, and Standard-Setting", May 2000, available at http://ideas.repec.org/p/cla/levarc/122247000000000539.htmlhttp://ideas.repec.org/p/cla/levarc/122247000000000539. $\underline{\mathrm{html}}$, J. M. Buchanan and Y. J. Yoon, 'Symmetric Tragedies: Commons and Anticommons', Journal of Law and Economics 2000, 43(1), 1-14.

18 Microsoft's Interoperability Undertakings of December 16, 2009 are intended to resolve this lock-in issue. See above, footnote 9.

19 Broadcom Corp. v. Qualcomm Inc., 501 F.3d 297, 310 (3d Cir. 2007), III.A.2.b.: “Although a patent confers a lawful 
opportunity for unscrupulous IPR owners whose intellectual property is essential for the standard. In the example of $3 \mathrm{G}$ cell phones mentioned above (with about 6,000 patent families for the air interface alone), even if all patent owners agree to license, each may have an incentive to threaten manufacturers with an injunction, a threat to kill their business, to extract extortionist fees - the commercial counterpart of Dick Turpin's "Your money or your life". A hold-up using a single patent on a single component can kill an entire product. Because cooperative innovation in today's IT and telecom products fragments technology ownership (the 6,000 patent families mentioned above are owned by dozens of different firms), this risk is multiplied many times. If one patent holder makes his get-away after holding up another, others are encouraged to do the same.

When first confronted with this problem, industry players responded by developing a portfolio of countervailing patents. This is like an arsenal of nuclear missiles, with everybody pointing a missile at everyone else. If one player asserts patent rights against another, it is immediately counter-sued by the accused party. Firms even enter into mutual defense pacts. ${ }^{20}$ This cold war situation of Mutually Assured Destruction is hardly ideal. Too much effort goes into mining patents on too many trivial ideas. More important, it is no defense against patent trolls, nonvertically integrated firms that mine patents or buy them up from bankrupt estates to join a feeding frenzy, and who have nothing to lose from a counter-suit, since they do not engage in production. ${ }^{21}$ The IPCom and Rambus cases come to mind. ${ }^{22}$ In a situation like this, strength becomes a weakness, since the largest producers are most vulnerable to the smallest opportunistic patent holder. This asymmetrical warfare even creates opportunity for strategic behaviour, where manufacturers are tempted to finance third-party IPR litigation against competitors, ${ }^{23}$ or to spin off patent portfolios to kill rivals or hold them up with a view to raising rivals' costs. ${ }^{24}$ If you can't

monopoly over the claimed invention [...] its value is limited when alternative technologies exist [...] That value becomes significantly enhanced, however, after the patent is incorporated in a standard [...] Firms may become locked in to a standard requiring the use of a competitor's patented technology. The patent holder's IPRs, if unconstrained, may permit it to demand supracompetitive royalties." See also C Madero Villarejo and N Banasevic, "Standards and Market Power", Global Competition Policy, May 2008, 3.

20 Examples include the open Innovation Network (OIN, http://www.openinventionnetwork.com/), the Allied Security Trust (http://www.alliedsecuritytrust.com/http://www.alliedsecuritytrust.com/ ), Intellectual Ventures (http://www.intellectualventures.comhttp://www.intellectualventures.com ) and RPX Corporation ((http://www.rpxcorp.comhttp://www.rpxcorp.com ). While many of these may be beneficial, the model is not without risk to industry and consumers, since some of the profit-oriented entities might eventually be tempted to evolve into a Ponzi scheme, start holding up industry members that have not joined them, or resell the patents to third parties that do so.

21 Trolls are sometimes called "non-practicing entities". New technology business models such as patent trading and "patent mining" are not necessarily bad. The existence of a market for patents may foster innovation, and allow firms or groups like the Open Innovation network to acquire patents for defensive purposes. At the same time, patent traps and royalty traps ("hold-up") may discourage investment, where remuneration is taken away from the person who incurred R\&D costs and bore the risk of product development - in a situation where bringing products to market may well be more costly, more risky and more beneficial to consumers. The key is to intervene to prevent inefficient holdups, including "opportunistic behavior on the part of patent owners that threatens to impose (1) static deadweight losses that are not justified by likely increases in dynamic efficiency, or (2) dynamic efficiency losses due to reduction in the incentive to participate in standard setting organizations or to engage in follow-up innovation." See T. Cotter, "Patent Holdup, Patent Remedies, and Antitrust Responses", Journal of Corporations Law, July 1, 2009, available at http://www.allbusiness.com/legal/civil-procedure-injunctions/12938773-1.htmlhttp://www.allbusiness.com/legal/civilprocedure-injunctions/12938773-1.html .

22 See above, footnotes 11 and 12.

23 A well-known example is Microsoft's financing of SCO to assert copyrights against Linux. See discussion at Groklaw, http://www.groklaw.net/staticpages/index.php? page=20061212211835541http://www.groklaw.net/staticpages/index.php?page=20061212211835541 .

24 An interesting example is Microsoft's attempt to quietly auction off 22 Linux-focused patents to non-vertically 
beat them, join them. Impenetrable patent thickets exacerbate the problem, because it becomes too difficult to challenge each and every patent used in the hold-up. The result can stifle innovation, standardization, and implementation of standards, for fear of future hold-up.

To address this problem, courts can take off the hard edges of intellectual property, as the US Supreme Court did in Quanta v. LGE (expanding the reach of exhaustion rules) and eBay $v$. MercExchange (limiting availability of injunctive relief subject to principles of equity, in case of patent suits by non-practicing entities), the German Federal Supreme Court did in Orange Book (limiting availability of injunctive relief under competition law where the dispute is merely about the amount of a FRAND royalty) and the Dutch Court of The Hague suggested could be done in Philips v. SK Kassetten. ${ }^{25}$ Legislatures can adjust patent laws, as the EC is proposing to do by proposing "license of right" arrangements. ${ }^{26}$ Private parties cooperate, agreeing to avoid patents altogether as the open source community does, ${ }^{27}$ requiring royalty-free licensing as $\mathrm{W} 3 \mathrm{C}$ has chosen to do ${ }^{28}$ by encouraging patent pools as DVB does, ${ }^{29}$ by agreeing to mutual price restraints as ETSI tried to do with its duty to disclose IPRs and license them on FRAND terms before

integrated patent companies, explaining how these could be used to against Linux, which was unexpectedly thwarted by Allied Security Trust buying them and reselling them the Open Innovation Network. See Groklaw, "Microsoft and A Patent Checkmate of My Dreams”, available at http://www.groklaw.net/articlebasic.php? story=20090908164954318http://www.groklaw.net/articlebasic.php?story=20090908164954318 .

25 Quanta Computer Inc. v. LG Electronics, Inc., 453 F. 3d 1364; eBay Inc v. MercExchange, L.L.C., 547 U.S. 388 (2006); Bundesgerichtshof KZR 39/06, decision of May 6, 2009, Rechtbank te's-Gravenhage, 17.03.2010, Philips/SK Kassetten $\mathrm{GmbH}$. (FRAND defense rejected on the ground that infringer could and should have applied to the court for a compulsory license on FRAND terms).

26 See Revised proposal for a Council Regulation on the Community Patent, April 7, 2009, Article 20, available at http://register.consilium.europa.eu/pdf/en/09/st08/st08588.en09.pdfhttp://register.consilium.europa.eu/pdf/en/09/st08/st 08588.en09.pdf. The "license of right" is voluntary, and to have practical impact, additional incentives are probably required to encourage patent holders to agree with the license of right regime, for instance by facilitating the challenge of injunction patents, and by allowing "license of right" patents a greater presumption of validity. Moreover, defensive suspension of the "license of right patent" should be introduced, so as to allow defensive use. For some interesting articles see e.g. Boldrin and Levine "The Case Against Intellectual Property", (2002) American Economic Review 92(2): 209-212 and M.A. Lemley, “A Cautious Defense of Intellectual Oligopoly With Fringe Competition”, (2009) Review of Law \& Economics, Vol. 5 : Iss. 3, Article 3.

27 "Open source software is software that is distributed under an open source license. The open source license gives anyone who is interested the right to access the program's source code and to copy, modify, and redistribute the program on a royalty free basis. There are many different open source licenses, but these characteristics are common amongst all of them. The most popular open source software programs also use an open source development methodology. An open source methodology provides any interested programmer with access into the program development process, and a democratic, open means for development and enhancement of the program. Software can be open source even if the developers do not adopt an open source development methodology. Open source software is complementary to, and is often included in, commercial software. [...] Open source software can be an important source of innovation because it brings together people from different backgrounds and perspectives to work on and solve common business and IT problems. It is also an excellent approach for driving emerging standards and, in many cases; an open source software project can become the common implementation of a standard that is used by a large number of IT vendors and customers." See IBM paper "Open Standards, Open Source, Interoperability and Government Policy”, May 11, 2009, http://www.marketwire.com/press-release/Ibm-NYSE-IBM902622.htmlhttp://www.marketwire.com/press-release/Ibm-NYSE-IBM-902622.html .

28 See W3C Patent Policy, available at http://www.w3.org/Consortium/Patent-Policy20040205/http://www.w3.org/Consortium/Patent-Policy-20040205/ .

29 See DVB Project promotes Pooling of DVB Patents, May 29, 1997, available at http://www.dvb.org/documents/pressreleases/pr037_promotes\%20Patent\%20Pooling.pdfhttp://www.dvb.org/documents/press-releases/pr037_promotes $\% 20$ Patent\%20Pooling.pdf . See also C. Shapiro, "Navigating the Patent Thicket: Cross Licenses, Patent Pools, and Standard-Setting”, May 2000, available at http://ideas.repec.org/p/cla/levarc/122247000000000539.htmlhttp://ideas.repec.org/p/cla/levarc/122247000000000539. html. 
finalizing the standard, ${ }^{30}$ or by the use of competition laws or regulation.

These solutions tend to be effective only if they result in truly "open standards". To qualify as "open", the process for standards adoption, quality, and access to the standard must meet a number of conditions, all of which are needed to eliminate the tragedy of the anti-commons. ${ }^{31}$ The following list includes several criteria: ${ }^{32}$

a. Open access to the decision-making process. No interested party should be excluded, unless on the basis of published, objective, relevant, proportionate, and verifiable criteria for admission. ${ }^{33}$

b. Open (transparent and undistorted) procedures. ${ }^{34}$ Governance rules for standards bodies should ensure that technology decisions, voting, and dispute resolution are representative, objective, and protected from undue influence. Vote stuffing or procedural irregularities such as alleged with respect to OOXML, for instance, disqualify a standard as open. ${ }^{35}$

30 See ETSI IPR Policy and Guide on IPRs, available at http://www.etsi.org/WebSite/AboutETSI/IPRsInETSI/IPRsinETSI.aspxhttp://www.etsi.org/WebSite/AboutETSI/IPRsI nETSI/IPRsinETSI.aspx . See also "The Way Forward for IPR", above, footnote 4. M. Lemley, "Ten Things to Do About Patent Holdup of Standards (and One Not to)", (2007) 48 B.C. L. Rev. 149, 151-55 (2007). For an overview of IPR Policies, see also A. Updegrove, The Essential Guide To Standard, Chapter 4, Intellectual Property and Standard Setting, available at http://www.consortiuminfo.org/essentialguide/intellectual.phphttp://www.consortiuminfo.org/essentialguide/intellectua 1.php.

31 This is not to suggest that closed standards are prohibited. Joint R\&D not intended to create an industry standard may meet the conditions of the Joint R\&D Block Exemption Regulation No. 2659/2000, OJ L 304/7 (2000) or the Guidelines for Horizontal Agreements, above. Similarly, proprietary standards fairly achieved may be beneficial in fostering radical "break-out" innovation like Sun's Java and the very notion of cloud computing to "escape" the local desktop or local network. Thus, open standards should not be mandatory, so long as the owner of the proprietary standard - if and when it prevails and develops network effects - is curbed from using its dominance to stifle "breakout" innovation.. Also, closed standards should not be given any preference in procurement, and may not obtain all the benefits of European standards.

32 See also European Commission, White Paper, Modernising ICT Standardisation in the EU - The Way Forward, $\operatorname{COM}(2009) 324$ final, July 3, 2009, p. 4-6; IBM paper "Open Standards, Open Source, Interoperability and Government Policy", May 11, 2009, and "IBM Announces new IT Standards Policy”, September 23, 2008, http://www.marketwire.com/press-release/Ibm-NYSE-IBM-902622.htmlhttp://www.marketwire.com/pressrelease/Ibm-NYSE-IBM-902622.html and http://www.sutor.com/newsite/blog-open/? $\mathrm{p}=2615 \mathrm{http} / / / \mathrm{www}$.sutor.com/newsite/blog-open/?p=2615; Microsoft Interoperability Principles, February 21, 2008, http://www.microsoft.com/interop/principles/default.mspxhttp://www.microsoft.com/interop/principles/default.mspx ; and "The Meaning of Open", in The Official Google Blog, December 21, 2009, http://googleblog.blogspot.com/2009/12/meaning-of-open.htmlhttp://googleblog.blogspot.com/2009/12/meaning-ofopen.html . For an in-depth discussion of these criteria from a competition law perspective, see also M. Dolmans, "Standards for Standards" Vol 26, Fordham Int'l L. J. number 1, November 2002, p. 163-208 and "Standard Setting The Interplay with IP and Competition Laws - How to avoid false FRANDs", 2008 Fordham IPR Conference, in Hugh C. Hansen (ed.), Intellectual Property Law and Policy, Volume 12 (forthcoming).

33 See Guidelines on Horizontal Agreements, above, footnote 6. See also European Commission Decision 87/69/EEC of 15 December 1986 relating to a proceeding under Article 85 of the EEC Treaty (IV/31.458 - X/Open Group), OJ L35, February 6,1987, p. 36, requiring that if access is so limited, an exemption under Article 101(3) TFEU may still be available if the results are licensed openly. Access to the decision-making process can slow or distort progress, but skewed access can lead to distortions and inefficiencies in upstream technology competition and downstream implementation competition. Having objective, relevant and proportional rules for access appears to be the best way to strike the balance.

34 See Commissioner Kroes' OFE Speech, above, footnote 7: "Allowing companies to sit around a table and agree technical developments for their industry is not something that the competition rules would usually allow. So when it is allowed we have to look carefully at how it is done."

35 See R. Weir "The Final OOXML Update", above, footnote 10, and G. Moody, "Microsoft, OOXML and the ISO: the Response", July 13, 2009, available at http://www.linuxjournal.com/content/microsoft-ooxml-and- 
c. Open (published, pro-competitive) goals. Standards unnecessary for or not reasonably related to clearly defined, legitimate objectives such as interoperability, are naked restraints of intertechnology competition, and should not be allowed. ${ }^{36}$

d. Open (published, objective, relevant, qualitative, and verifiable) criteria for technology selection. Standard agreements should be based on the relative merits and price of the technologies involved, to the extent possible. Of course, the advantages, performance and costs of technologies cannot always be known before adoption as a standard. But openness will aid a well-informed debate and choice, and minimizes the risk that standard setting is used as a cloak for an inefficient cartel or a tool to distort inter-technology competition

e. No overstandardization. A standard should be no more restrictive than necessary to meet the objective, and should allow maximum consumer choice without lock-in to a single vendor's product. Where possible, design specifications should be avoided to ensure maximum competition within the standard on quality and product differentiation.

f. Open access to the standard. A standard is "open" only if it is well-documented and published, and available for implementation for all interesting parties, members of the standards body and outsiders alike. This has several key components, relevant for IPR Policies of standards bodies:

- Open information on blocking patents. No one wants to expose himself to ex post hold-up. This means that to the maximum extent possible, patents, patent applications, and other IPRs that could block implementation should be made known as soon as reasonably possible before the standard is selected, so that informed decisions can be made whether the IPRs are available and at what terms.

- No unjustified refusal to license. Unjustified actual or constructive refusals to license essential IPRs, or unjustified delays, are inconsistent with open access to a standard. The right to refuse to license or obtain an injunction at will is the very cause of the tragedy of anti-commons, and therefore should be limited to situations where a refusal is necessary to prevent the opposite (the tragedy of commons, discouraging investment in R\&D). ${ }^{38} \mathrm{~A}$ refusal or injunction is justified, in other words, if licensee refuses in turn to license essential IPR on FRAND terms, or where the

isohttp://www.linuxjournal.com/content/microsoft-ooxml-and-iso . See also AlliedAllied Allied Tube \& Conduit Corp. v. Indian Head, Inc.Allied Tube \& Conduit Corp. v. Indian Head, Inc. , 486 U.S. 492 (1988).

36 Cf. Article 101(3) TFEU. Interoperability refers to the ability of information and communication technology systems and the business process they support to exchange data with fidelity and to enable sharing and utilization of information and knowledge. For citizens, interoperability means they can access, provide and utilize government information using the IT solutions of their choice, without being stymied by closed, proprietary hardware or software solutions that do not support open standards. See IBM paper "Open Standards, Open Source, Interoperability and Government Policy", above, footnote 32.

37 See Rambus, above, footnote 10.

38 It has been argued that injunctions should be allowed in standards context subject only to the criteria of abusive litigation, which would be the case if the proceedings cannot be regarded as an attempt to enforce legitimate rights but only serve to harass and if they are part of a framework of a plan to eliminate the competition (ITT/Promedia, [1998] ECR II-2937). But that ignores the crucial element distinguishing standard setting from a normal situation, namely, that the IPR owners have promised to license on FRAND terms, the standards organization has relied on it leading to an agreement to limit inter-technology competition that would otherwise have existed, and the industry has relied on it by making investments in innovation. Having made such a promise and obtained monopoly as a result, it should be an abuse of dominance to seek injunctive relief to extract royalties higher than those that would have pertained in ex ante inter-technology competition. 
licensee cannot pay or refuses to pay a FRAND rate. For the same reason, termination of a license should not be allowed at will, but only for (actual or anticipatory) material breach that cannot be remedied, or if the licensee refuses to license its essential IPR (“defensive suspension"). Finally, there should be no constructive refusal to license, for instance, by demands for treble damages or imposition of excessive fees. ${ }^{39}$ An injunction is not justified if the purpose is to magnify the bargaining power of the patentee and expropriate all or almost all profits that the defendant made or expects to make from a complex product implementing a standard. ${ }^{40}$ This raises the thorny question of fair pricing.

- Fair pricing. No one should be forced to buy a pig in a poke or expose himself to ex post blackmailing. Commissioner Kroes confirmed in her OFE Speech that "rates [must be] fair, and [...] based on the inherent value of the interoperability information (rather than the information's value as a gatekeeper)"and "we step in when companies rip-off consumers, in one way or another." ${ }^{41}$ Under Article 102(a) TFEU (ex 82 EC), indeed, dominant firms are prohibited from "directly or indirectly imposing unfair purchase or selling prices or other unfair trading conditions." This covers using market power derived from having been included in a standard, to charge excessive prices or impose unjustifiably onerous or unfair terms. The European Court of Justice has confirmed that it may be a violation of Article 102 TFEU (ex 82 EC) for an undertaking in a dominant position to charge a price that is excessive in relation to the economic value of the service provided or the good supplied. ${ }^{42}$ In Port of Helsingborg, the European Commission confirmed the "value" criterion and used various proxies to conclude that no violation had occurred in that particular case. ${ }^{43}$ To determine the inherent value, and prevent disputes as much as possible, competition law now allows ex ante open disclosures of prices and license terms, and even technology auctions. ${ }^{44}$ In complex standards, however, this is unfortunately often infeasible, because standards take several years to develop, with a sequence of

39 Cf. Orange Book case (German Supreme Court), judgment of May 6, 2009, KZR 39/06, on appeal from Court of Appeal Karlsruhe, Case 6 U 174/02, Orange Book-Standard. See also judgment of the Regional Court of Düsseldorf of Feb. 13, 2007 in Case 4a O 24/05, Siemens v Amoi (Zeitlagen-multiplexverfahren). Compare also Judgment of the District Court Düsseldorf, Case 4b O 346/05, Video Signal Encoding. German Federal Court of Justice, decision of 13/7/2004 - Standard-Spundfass II, WuW DE-R 1329, GRUR 2004, 966.

40 C. Shapiro, "Injunctions, Hold-Up, and Patent Royalties" (August 2006), available at http://faculty.haas.berkeley.edu/shapiro/royalties.pdfhttp://faculty.haas.berkeley.edu/shapiro/royalties.pdf ("patentees whose inventions are only one component of a larger product are systematically overcompensated. The reasonableroyalty floor for patent damages is designed to compensate a patent owner for losses it sustained as a result of infringement, not to punish or deter infringement or even to deprive an efficient infringer of all of the profits from that infringement. But the way reasonable royalties are calculated, particularly for component inventions, has made them into a tool for patentees to capture more than their fair share of a defendant's profit margins. [...] damages reform must be coupled with a solution to the holdup problems created by injunctions. [...] holdup problems in patent cases can be quite significant, but that a relatively simple step-a stay of injunctive relief sufficient to allow the infringer to design around the patent if it can in cases involving reasonable royalties but not lost profits-would significantly reduce that problem"). See also J Farrell, J Hayes, C Shapiro, and T Sullivan, "Standard Setting, Patents and HoldUp", (2007) Antitrust Law Journal 74(3) 638; M. Lemley and C. Shapiro, "Patent Holdup and Royalty Stacking”, (2007) Texas Law Review Vol. 85:1991-2049, at , http://faculty.haas.berkeley.edu/SHAPIRO/stacking.pdfhttp://faculty.haas.berkeley.edu/SHAPIRO/stacking.pdf .

41 Competition and Consumers in the 21st century", SPEECH/09/486 by Commissioner Kroes, October 21, 2009.

42 See General Motors v. Commission, [1975] ECR 1367, and United Brands v. Commission, [1978] ECR 207.

43 Case COMP/A.36.568/D3, Scandlines Sverige AB v. Port of Helsingborg, Commission Decision of 23 July 2004. See also M. Glader and S. Chabert Larsen, "Excessive Pricing and Article 82", Competition Law Insight, July 2006, at 3-5.

44 OFE Speech: "If we are to include proprietary technology in a standard, then ex ante disclosure [of essential patents and maximum royalty rates] may help those involved make a properly informed decision. Competition law should not stand in the way." 
selection decisions. Once a process is locked into a particular direction, technology choice for subsequent development is restricted. Initial experience with ex ante declarations of terms indicates that IPR owners have an incentive (a) to delay disclosures of their patents and the license terms until they have achieved a blocking position, (b) buy, swap or develop blocking patents for each alternative in order to prevent real inter-technology competition, ${ }^{45}$ and (c) once they have achieved a blocking position, rush to the table to claim the highest fee in an attempt to pre-empt other IPR owners' claims. In practice, therefore, there appear to be only two solutions to ensure open access: (1) a clear policy of avoiding all patents or insisting on royalty-free access, as W3C and the open source community do, or (2) a clear and enforceable policy of fair, and reasonable pricing.

The former option - a policy of avoiding all patents that are not available on royalty-free terms without restriction - is adequate and pro-competitive so long as it does not prejudice incentives to innovate. New revenue models suggest, in fact, that at least in the software sector, IPR protection is not the only model encouraging innovation. The W3C's Internet open standards are IPR-free or royalty-free, and are arguably one of the greatest platforms for innovation that the world has seen. Open source software development is encouraged by the prospect of revenues from upgrades, services and complementary products rather than on royalty income (although it depends on the existence of copyright to ensure that open source license conditions are passed on) ${ }^{46}$ Innovative advertising-funded or transaction-funded IT services do not rely on fees from users, and in twosided markets, giving away one product for free may generate demand for another fee-paying product. The development of free APIs and free interoperability information for a software platform pays for itself because it makes the platform more attractive as additional complementary products become available for it. ${ }^{47}$ The cost of bringing software to market is less then for tangible products. All of these factors are especially pertinent in industries where network effects are strong, because success feeds on itself and magnifies the potential income from these alternative revenue models. These examples from the software area suggest that software-to-software interoperability standards can and should be royalty-free. ${ }^{48}$ The beauty of royalty free interoperability standards is that they can be implemented in both open source and proprietary software, thus allowing both types of products to compete on quality and functionality.

In other areas, such as mobile telecommunications networks and computer hardware, the situation

45 Competition law may be powerless to block strategic patent acquisitions or swap arrangements of this kind, if the transactions do not meet the turnover thresholds for merger control. Qualcomm's acquisition of Flarion's IPR portfolio is an example.

46 See Y. Benkler's brilliant "Coase's Penguin, or, Linux and The Nature of the Firm", 112 Yale L.J. 369 (2002) http://www.yalelawjournal.org/112/3/369 yochai_benkler.htmlhttp://www.yalelawjournal.org/112/3/369 yochai_benk ler.html .

47 "The return is NOT necessarily about royalties. The return may be that a product that includes the standard as part of it will do better in the marketplace because of the broader adoption of the baseline technology as a standard. The return might be in improved interoperability of a given product or service due to the adoption of that standard. There are competitive reasons for contributions - the hope may be to displace a competitor who is using a non-standardized solution" (J. Matusow, "Balance of Contributors \& Implementers", August 2, 2009,

http://blogs.msdn.com/jasonmatusow/archive/2009/08/02/balance-of-contributors-implementers-a-blog-answer-to-rickjelliffe-s-post.aspxhttp://blogs.msdn.com/jasonmatusow/archive/2009/08/02/balance-of-contributors-implementers-ablog-answer-to-rick-jelliffe-s-post.aspx ). Similarly, the Apple iPhone truly took off when Apple opened up its APIs and applications became available.

48 See also European Commission, White Paper, Modernising ICT Standardisation in the EU - The Way Forward, $\operatorname{COM}(2009) 324$ final, July 3, 2009, p. 8-9, which recognizes the distinction between the software interoperability and the telecom network sector. 
appears different. No open source movement exists for telecommunications network technology. In these areas, mandating royalty-free licensing would likely recreate a tragedy of commons and discourage innovation, while allowing IPR owners to charge at will could create a tragedy of anticommons. To strike the right balance, therefore, a contract of mutual restraint is necessary. This was the intent of the IPR Rules adopted by ETSI in the 1990s, which called for essential IPR owners to commit (before a standard is finalized, at a time that inter-technology and inter-standard competition is still viable) to charge "fair and reasonable" royalties. ${ }^{49}$ This is also mandated by Article 101(3) TFEU (ex Art. 81(3) EC): in exchange for being allowed to restrict inter-technology competition by agreeing to choose one technology for a standard and exclude others, the conditions for exemption must be met: competition in the products implementing the standard must not be eliminated, and consumers must get a fair share of the benefit. It is also mandated by Article 102(a) and (c) TFEU (ex Art 82(a) and (c) EC) which prohibit a dominant firm (the owner of ex post essential patents) from imposing unfair and discriminatory terms, especially where licensees made investments in legitimate reliance on the FRAND promise.

Unfortunately, a contract of mutual restraint can exist only if and so long as everyone plays by the rules. If one patentee breaks ranks and charges the highest royalty it can get away with, would the others grin and bear it, and lower their fees to absorb the price increase? It has been suggested that this would in fact happen, even that it would be "fair and reasonable" and consistent with competition law and FRAND promises for a non-vertically-integrated licensor to extract an amount close to full monopoly rent for a patent, leaving the crumbs for the other licensors and licensees. Consumers will not suffer, the argument goes, since a rational analysis of an "ultimatum game" indicates that (a) licensors of complementary essential patents will restrain themselves and seek only the difference between the royalty charged by the first licensor and the monopoly rent, so as to avoid a "Cournot complements" problem, and (b) licensed manufacturers will maintain the price for the end product and lower downstream profits (reducing their reward for innovation and risk downstream).

This argument is probably correct in cases where two cumulative conditions are met: (a) the patents were ex ante essential, absent viable alternatives, and (b) no complementary essential patents nor downstream innovation are needed..$^{50}$ If those conditions are met, there was no inter-

49 See ETSI IPR Rules and ETSI Report “The Way Forward for IPR", above. That the intent was a call for mutual restraint in royalty setting is confirmed by various industry statements, including "NTT DoCoMo, Nokia, Siemens and Japanese manufacturers Reach a Mutual Understanding to Support Modest Royalty Rates for the WCDMA

Technology Worldwide”, 6 November 2002, available at http://www.umts-forum.org/http://www.umts-forum.org/ and "Wireless Industry Leaders Commit to Framework for LTE Technology IPR Licensing", statement of 14 April 2008 by Alcatel-Lucent, Ericsson, NEC, NextWave Wireless, Nokia, Nokia Siemens Networks and Sony Ericsson, available at http://www.ericsson.com/ericsson/press/releases/200804141209031.shtmlhttp://www.ericsson.com/ericsson/press/releases/20080414-1209031.shtml . See also http://www.nokia.com/A4993368http://www.nokia.com/A4993368 and http://www.ericsson.com/technology/licensing_programs/index.shtmlhttp://www.ericsson.com/technology/licensing p rograms/index.shtml . Cf. also Siemens v Amoi (Zeitlagenmultiplexverfahren), District Court of Dusseldorf, 13 February 2007, 4aO124/05 and Nokia Corporation v Interdigital Technology Corporation [2007] EWHC 3077.

50 Cf. Motorola v Rockwell int'l Corp, No 95-575-SRL (D.Del 1995). This should be distinguished from the 2004 decision in Microsoft, which concerned software interoperability (see fn. 2 above), was a remedy, and where patents were not ex ante essential. In that case, the Commission appropriately distinguished between two types of "value" transferred to competitors by the compulsory license that the Commission imposed, in a way that is also relevant to standards cases. It differentiated between (a) "strategic value' stemming from Microsoft's market power", and (b) value derived from true innovation. The former is the amount that Microsoft could extract in a hold-up of the users of its interoperability information, considering that the industry cannot avoid that information because of the need for 
technology competition to begin with, and the standard agreement is not caught by Article 101(1) TFEU. But if (a) the patents were not ex ante essential or (b) implementation requires complementary patents from other licensors, there are several reasons why this cynical "first mover takes all" approach will not be "fair and reasonable" - apart from the consideration that it will not sound "reasonable" to the proverbial "man in the Clapham Omnibus." 51

First, in the EU (and unlike Section 2 of the Sherman Act in the US), Article 102(a) and (c) TFUE prohibit unfair pricing or unjustified discrimination even in the rare case where no ex ante competition existed, so long as consumer harm ensues from excessive or discriminatory pricing. A "first mover takes all" approach could cause consumer harm by discouraging cooperation by other patentees and reducing investments by licensees in setting and implementing the standard, while the prospect that this is allowed in standard setting generally would dampen the incentives for dynamic competition by developing new technologies that could be used for future standard generations. Article 102 TFEU is appropriately applied where excessive or discriminatory pricing discourages standard implementation, investment in R\&D for future standards, or future standard setting, or where it results in a "Cournot problem" or a "game of chicken" (see below). In the US, this may be caught by Section 5 of the US FTC Act.

Second, in game theory, it may indeed be a rational response to an "ultimatum game" for colicensors and licensees to lower their revenue expectations to ensure that the total royalty stack does not exceed monopoly rent. But this is the kind of theory that earns some economists the definition of "academics who tell you why what happens in market reality is impossible in theory." In commercial reality, co-licensors cannot estimate what the monopoly rent is, and will likely try (especially if they have not sunk investments in implementation of the standard) to capture more than the crumbs left by the cynical first-moving licensor. They will want equal or greater remuneration if their technical contribution to the standard was equal or greater as the first mover's. They can do that by raising their rates to the same level as the first licensor, to try and force his rate down - what game theorists call a "game of chicken". They need not even raise rates, but could, for instance, spin off part of their patent portfolio to create one or more additional

their servers to communicate with Microsoft clients and servers on an equal footing as Microsoft's servers. The latter is the value derived from true innovation, i.e., the ex ante incremental value (if any) over the next best alternative had there been open standardization and an auction before Microsoft became dominant in client PC operating systems and the industry was locked in. See Microsoft Commission Decision of Mar. 24, 2004, Case COMP C-3/37.792, Commission v. Microsoft Corp., 2007 OJ L 32, p.23-28, II 1008. The question whether Microsoft's penultimate royalty offer was "fair and reasonable" was addressed in Decision of the European Commission C(2008) 764 final of 27 February 2008 fixing the definitive amount of the periodic penalty payment imposed on Microsoft. This decision is subject to appeal. Case T-167/08, Microsoft v. Commission, OJ C 171/41, July 5, 2008.

51 In an "ultimatum game", one person is asked to share a stack of money with an unknown counterpart, who can react either by agreeing (in which case the counterpart receives what was offered, and the offeror keeps the rest) or by vetoing (in which case neither party receives anything). The "subgame perfect Nash equilibrium" (the optimal rational outcome) is that the first moving licensor (the offeror) receives close to monopoly rent and the remaining licensors and licensees (the offerees) receive just enough not to turn them away from licensing and implementing. Experimental game theory indicates, however, that most people do not consider the purely rational optimal outcome "fair and reasonable". Ordinary individuals playing ultimatum games tend to share more than the rational minimum with their counterpart. This is known as "iniquity aversion." Cf. for instance A. A. Stanton, "Evolving Economics: A Synthesis", April 26, 2006, available at http://mpra.ub.uni-muenchen.de/2369/http://mpra.ub.uni-muenchen.de/2369/ . These studies are relevant, because they gives an indication of what reasonable participants in standards bodies (who are not economists, but normal individuals) in fact expect from each other when agreeing on FRAND licensing. See also “Standards, IP and Competition: De Aequitate Non Est Disputandum?", Helsinki, October 7, 2009, available at http://www.iprinfo.com/tiedostot/Dolmans.pdfhttp://www.iprinfo.com/tiedostot/Dolmans.pdf . 
licensors charging equivalent or higher rates for their "new" portfolio. As the IPCom and N-Data cases indicate, any FRAND promise travels with the spun-off patents, but if a FRAND duty were in fact interpreted to leave freedom to charge whatever the market can bear, as opposed to an amount proportionate to the "value" or total technical contribution to the standard, a FRAND promise is no constraint. The result is a mutual hold-up or a prohibitively high royalty stack, all or part of which will be passed on to consumers, ${ }^{52}$ and possibly even failure of the standard.

Economic analysis provides a framework for analysis to avoid this tragedy of anti-commons, by defining a "fair and reasonable" royalty not as the rate that the market can bear ex post or that the first mover demands, but as the lower of (a) the rate that the IPR owner could have obtained in an ex ante inter-technology auction, with different technologies competing for the standard, before the investments are finalized (ignoring any anti-competitive actions or patent acquisitions by the IP owner that diminish ex ante inter-technology competition), ${ }^{53}$ and (b) if the IPR owner had an ex ante blocking patent, a share of the royalties that is proportionate to the technical contribution the IPR owner made to the standard compared to that of other essential patent owners and taking into account the investments made and risks borne by the licensees. As Commissioner Kroes said in her OFE Speech in 2008: "I fail to see the interest of customers in including proprietary technology in standards when there are no clear and demonstrable benefits over non-proprietary alternatives." The logical extension of that argument is that if there are clear and demonstrable benefits, the total royalty should be no more than the value of these benefits, i.e., the value that licensees can derive from using the selected technology over and above the value they could have derived from the next best alternative. If the necessary information is not available, economists can do a "Shapley value" analysis, or use proxies, such as: $:^{54}$

i. A comparison with royalties and terms that other owners of essential patents reading on the

52 If all licensees face higher royalties, all would pass them on $100 \%$ to consumers. Even if only patent-poor licensees paid high royalties (with patent rich licensees negotiating a royalty reduction for a cross-license), they would still have the incentive to pass these on to consumers, and patent-rich licensees would likely respond by raising their prices as they face less competitive pressure. Economic analysis indicates, therefore, that consumers suffer either way.

53 D Swanson and W Baumol, "Reasonable and Non-discriminatory (RAND) Royalties, Standards Selection, and Control of Market Power” (2005) 73 Antitrust Law Journal 7. Quoting Swanson and Baumol, the US FTC held in Rambus that a reasonable royalty "is or approximates the outcome of an auction-like process appropriately designed to take lawful advantage of the state of competition existing ex ante [...] between and among available IP options. "In the Matter of Rambus Inc., FTC Docket No. 9302, Opinion of the Commission on Remedy, February 5, 2007 , at 17. For further refinements, see also S. Besen and R Levinson, "Standards, Intellectual Property Disclosure, and Patent Royalties After Rambus", 10 N.C. J.L. \& Tech. 233 (2009), available at http://cite.ncjolt.org/10NCJLTech233http://cite.ncjolt.org/10NCJLTech233 .

54 See United Brands v. Commission, [1978] ECR 207 and subsequent cases on excessive pricing. A Shapley value analysis describes a way to fairly allocate gains derived from cooperation among several actors. See http://en.wikipedia.org/wiki/Shapley_valuehttp://en.wikipedia.org/wiki/Shapley value . Honesty dictates that I admit to not fully grasping the mathematics, but the upshot is that each player obtains a share of the gains that is roughly proportionate to the relative value of his or her contribution. If one player has found a right hand glove and a second player has found a left hand glove, and the goal is to create a pair that can be sold for 6 Euro, both share the revenues 50/50. If two players have found right hand gloves and a third player has found a left hand glove, and the goal is to create a pair that can be sold for 6 Euro, the third player gets $2 / 3$ of the revenues (4 Euro), whereas the first or second player receive 1/6 (1 Euro). (The consumer presumably receives a 1 Euro discount, benefiting from competition between players 1 and 2.) In an ultimatum game, the hard-nosed optimal rational outcome would be for the third player to offer marginal cost +1 cent to each of players 1 and 2, allowing the third player to keep 5.99 Euro for himself (since they found the gloves and have no marginal costs). It's rational, but is it fair? Interestingly, it appears that the outcome of a one-shot experimental ultimatum game played by Western players would in most cases also result in player 3 receiving 2/3 (4 Euro) and leaving 1/3 (2 Euro) to player 1 and/or 2. 
same standard charge for their complementary patents ("proportionality analysis");

ii. A comparison with royalties and terms that the patent owner itself charges for other, comparable, technologies ("proxy analysis");

iii. The "Goldscheider analysis" (which is, however, controversial), which suggests that IP owners in the aggregate should generally be entitled to about 25 percent of the downstream gross profits made on the licensed product. ${ }^{55}$

Proxies are imperfect, but if an IP owner considers that its patents are worth more than a proportionality or proxy analysis suggests, it can (and bears the burden to) prove that its patents are less vulnerable to challenge, have broader geographic scope or a longer life, convey more value compared to the next best ex ante alternative, etc than the other essential patents, or that it bore greater risk than usual compared to licensees. There is precedent for this switch in the burden of proof. ${ }^{56}$

- Non-discrimination and no restriction of competition. Participants in standards bodies cannot reasonably be expected to agree to a standard including patents to which they have no access on the same basic terms as other companies implementing the standard. Differential treatment without objective and proportionate justification tilts the competitive playing field and thus prejudices open access. This reduces efficiencies and distorts competition between downstream players to find the optimal implementation. It is, moreover, a way to circumvent royalty constraints, allowing the patent owner to extract monopoly rent by monopolizing the downstream market for products implementing the standard. It is, in fact, a more effective way to do this, since it is difficult to change contractually fixed royalty rates, whereas it is easy for a monopolist to adjust prices for implementations to maximize profits. Monopolizing the downstream market creates the additional problem that it allows the monopolist the ability to manipulate supplies in order to put pressure on members of standards bodies who might otherwise have moved to avoid the monopolist's patents when setting the next standard. ${ }^{57}$

For these reasons, terms and conditions or price squeezes that have the object or effect of restricting downstream competition, or differential treatment based on whether licensee purchases the licensor's downstream product, should not be allowed under Articles 101(3) and 102 TFEU. ${ }^{58}$

55 R. Goldscheider, New Companion to Licensing Negotiations: Licensing Law Handbook II 7.02[8][b] (2003-2004 ed.). In determining the final percentage, adjustments should also be made for the enforceability and essentiality of the patents, the geographic scope of various patents and their remaining life, the costs of complementary technology needed, the value conveyed by the patents compared to the next best ex ante alternative, the risk borne and investments made by the licensee relative to the costs and risks borne by the licensor, the volume of sales expected in the market, and so forth. It should be adjusted downwards for instance, in situations where the licensees take more than the usual risk, or where there were adequate alternatives for the patents in question. But see Uniloc USA Inc. et al. v. Microsoft Corp. et al., case number 2010-1035, in the U.S. Court of Appeals for the Federal Circuit, January 4, 2011 ("This court now holds as a matter of Federal Circuit law that the 25 percent rule of thumb is a fundamentally flawed tool for determining a baseline royalty rate in a hypothetical negotiation. Evidence relying on the 25 percent rule of thumb is thus inadmissible under Daubert and the Federal Rules of Evidence, because it fails to tie a reasonable royalty base to the facts of the case at issue.")

56 Cf Case C-395/87 Ministère Public v Tournier [1989] ECR 2521, [1991] 4 CMLR 248, para 38.

57 See M. Dolmans, "Standard Setting - The Interplay with IP and Competition Laws - How to avoid false FRANDs", 2008 Fordham IPR Conference, in Hugh C. Hansen (ed.), Intellectual Property Law and Policy, Volume 12 (forthcoming).

58 See also Korean FTC Press Release "KFTC took corrective measures against Qualcomm for abusing its monopoly 
Nor should IPR owners be permitted to extract inadequately remunerated cross-licenses, which reduce incentives to innovate in standards implementation and inter-standard competition. ${ }^{59}$ Especially in the case of manufacturers controlling large market shares or in the case of de facto or de jure-mandatory standards, finally, standardization must not be exclusive and must not prevent the use of additional technology, or the development of competing standards. In the software-tosoftware interoperability area, where open source is a driver for innovation, this means that open standards licensing policies (to the extent they allow inclusion of patents in standards) should be open source compatible or at least not discriminate against open source.

To summarize, "The acid test for an open standard is whether or not it actually permits substitutability and choice among independent, multi-vendor implementations on different technology platforms with acceptable levels of functionality. The diversity of competing applications that support the standard is also an indication of its openness. " ${ }^{60}$ And under Article 101(3) TFEU (ex 81(3) EC), the license arrangements should be "allowing consumers a fair share of the resulting benefit" and "not [...] afford [...] undertakings the possibility of eliminating competition."

It is interesting to see how this call for open standards fits in upcoming Commission policy in the area of ICT. RAND Europe recently published a report for DG Information Society, entitled "Trends in Connectivity Technologies and their Socio-Economic Impacts - Policy Options for the Ubiquitous Internet Society" (the "RAND Report). ${ }^{61}$ Behind this somewhat impenetrable title are 200 densely written pages with a complicated - but quite interesting - analysis that may well serve as the foundation for DG Information Society's ICT Policy in the next decade. The RAND Report identifies a number of current technical and economic trends, which could lead to three possible scenarios for what the Internet may look like by 2020, reflecting distinct combinations of public vs. private governance, open vs. closed technologies, and competitive vs. collusive markets, including the following two extremes, whose description is revealing in itself: ${ }^{62}$

- The Scattered World scenario (the Internet in 2020 as collection of competing networks based on closed technology) reflects a "future of cutthroat monopolistic competition, unrestrained by active and effective antitrust and other regulation [...]. The fragmentation of competition and low levels of vertical and horizontal integration have as a counterpart low levels of inclusion and worrying

market status in modem chip market; Imposition of fine and issuance of corrective order for discriminative royalty rates, conditional rebates, etc", July 23, 2009. The EC Commission's case-law and practice in the context of essential facilities suggests that licensors of patents that are essential for compliance with a de jure or de facto mandatory standard should ensure separate accounting for their downstream manufacturing of standard-compliant products, so as to be able to demonstrate that they do not give competitive advantages to their own manufacturing divisions that they withhold from outsiders. The usual objection under US law against price squeeze analysis (that if the supplier has no duty to supply, it cannot have a duty to avoid price squeezing) does not apply where the IP owner promised to license on RAND terms.

59 See also Japan FTC Cease and Desist Order Against Qualcomm, September 20, 2009 (on appeal) available at http://www.jftc.go.jp/e-page/pressreleases/2009/September/090930.pdfhttp://www.jftc.go.jp/epage/pressreleases/2009/September/090930.pdf .

60 See IBM paper "Open Standards, Open Source, Interoperability and Government Policy", above, footnote 32.

61 Study conducted for DG Information Society and Media, July 2009, available at http://ec.europa.eu/information_society/activities/foi/library/docs/final-report-nosecclean.pdfhttp://ec.europa.eu/information_society/activities/foi/library/docs/final-report-nosec-clean.pdf ("RAND Report").

62 RAND Report, above, footnote 61, p. xix. 
levels of inequality."

- The Connected World scenario (the Internet in 2020 as a network based on open technology, driven by public investments and collaboration between firms) paints a "future where companies collaborate [...] [and] governments [...] take a cooperative lead in setting rules to optimise global public value creation [...]. [F]irms have to compete (and make their money) on the merits of what they provide rather than the ability to exclude rivals. [...] [I]nteroperability is a powerful public good, and governments are particularly vigilant against the risk of foreclosure by «bottleneck» firms or proprietary standards, using antitrust regulation, support for open standards and targeted public procurement to ensure a sustainably level playing field with high quality of service and reasonable prices. A potential limiting factor is that the speed of innovation [...] is slowed by the natural pace of government initiatives [...]. This world is very inclusive, including excellent technologies to assist those that need assistance to participate."

For each scenario, RAND analyzes the expected status of innovation, consumer choice, privacy, social cohesion and equality, and identifies a number of critical problems, positive developments, and uncertainties. Experts were then asked to look back from the future and identify the key policy choices that will create desirable outcomes and those that create problems. The report discusses IPRs, privacy, data protection, infrastructure investment, e-commerce and other policy issues. Interesting conclusions are also drawn with respect to open standards and interoperability and net neutrality. RAND mentions, for instance that "The interconnectedness of the [Internet] challenges competition as the sustainable engine of continual improvement. Network externalities favour 'tipping' into monopoly and competition weakens" and the report worries that this may give rise to "a desire to limit interoperability [more] than a desire to innovate and offer effective choice."

RAND concludes (p. 132) that Europe and most other major jurisdictions have not tried to regulate the Internet, but "as its spread and importance increase, this may no longer be possible, especially as other regulated activities 'escape' on-line and new policy concerns emerge." The report warns that alternatives to regulation should be considered early in the policy process. For instance (p. $\mathrm{xxvi}$, "the EC can encourage efficient competition among technologies and discourage inefficiently-high incompatibility, through creation or coordination of multi-stakeholder platforms and networks, and by applying multi-stakeholder governance principle. These would be enabling the adoption of common standards and market wide approaches to public policy concerns." Open standards as defined above would appear to present a perfect mix of flexible multi-stakeholder arrangements, ensuring an adequate balance between the need to foster private sector innovation and the need to avoid technological lock-in or gridlock. Indeed, the RAND Report (p. 145) identifies a dozen or so of key goals for DG Information Society to pursue, which include:

- "Guarding openness and open networks";

- "Champion common standards and pre-competitive collaboration";

- "Champion interoperability in all its forms"

Drawing attention to economic analysis and using existing literature, the RAND report identifies various tools and associated challenges to achieve these goals (p. $141 \mathrm{ff}$ ), which it is worthwhile to mention: 
- RAND proposes to use a range of ex ante and ex post regulation such as spectrum allocation, competition regulation, telecommunications pricing, interconnection, content regulation, fair competition and merger regulation, consumer protection, privacy, etc. At the same time, it identifies as a key challenge "to balance lightness of touch with credible effectiveness, [...] and to prevent capture and/or foreclosure that distort markets and the development of the Internet." Following the principles of open standards set out above should go a long way to meet this challenge, by maintaining adequate involvement of the private sector, while preventing capture and foreclosure.

- RAND approves of EC involvement in IPR regulation, to provide fair returns on risky inventive activity and as a market-based tool to signal where ideas are best applied. Interestingly, the report warns about the "the one-size-fits-all nature of the most common forms of IPR protection". The open standards approach described above is useful to avoid the problems of this "one-size-fits-all" IPR protection, for instance, by allowing for a royalty-free standards approach for software interoperability and royalty-bearing standards in telecommunications and hardware. Other key challenges RAND mentions are "the potential for failure in the market for IPR, the possibility that market power in the market for innovation will spill over into markets for goods and services or vice versa and the possibility that predatory use of IPR [...] and strategic incompatibility may undercut the hoped-for benefits." Again, the open standards framework described above would address these concerns, by encouraging standard setting to address incompatibility failures, and ensuring that the necessary patents are available on FRAND terms.

- RAND encourages standard-setting and support for standard-compliant products, including by thoughtful procurement policies in favour of open standards. RAND adds: "Key challenges here are to maintain openness of standards (to avoid lending public support to proprietary standards), to balance the interoperability advantages of standardisation against the potential loss of diversity and inhibition of innovation and to ensure that standardisation enhances the innovativeness and competitiveness of the European economy." While the RAND Report does not further define what "openness of standards" means, and does not propose ways to balance the need for interoperability against the need to maintain product diversity and innovation, it is submitted that the open standards principles mentioned above provide the solution that fits perfectly.

In one respect, however, there is a curious point in RAND's analysis, concerning the role of competition law to guarantee a system of open standards that maintains innovation while preventing IPR gridlock. The RAND Report (p. 131-132) worries about "the tendency of Internet markets to tip into monopoly" but then warns:

"Anticompetitive behaviour can't always be detected or prohibited ex ante, but ex post remedies (after lockin has occurred) may be too late, and there may be no counterfactual evidence to demonstrate that alternatives are viable if lock-in is widespread. Moreover, many of the specific activities that firms might use for predatory purposes (e.g. proprietary standards, low "penetration" pricing, etc.) are also essential in order to attract complementary content and services to Internet platforms capable of providing effective competition. Therefore, conventional antitrust policy may be less effective than consumer protection policy or supporting activities that enable users to coordinate moves to superior entrants, and participatory self-regulation may be more effective than IPR policy in deterring or overturning "stealth patents" in public standards." 
It is certainly legitimate to ask whether sector specific regulation should trump general antitrust regulation. With all due respect for the RAND Report, however, the conclusion in this paragraph and some of the thinking in it are at first sight hard to grasp.

First, what exactly are "activities that enable users to coordinate moves to superior entrants"? Does RAND propose that the Commission should itself compare different technologies and organize users to move towards solutions that the Commission thinks are superior? RAND recommends that the information needed to allow users to move to other platforms should be made available as a matter of public requirement, or made available by regulatory authorities themselves. ${ }^{63}$ This is consistent with the openness principles set out above. But RAND apparently goes further: where the mere provision of information is insufficient, public authorities might even coordinate or encourage moves to alternative platforms. It is submitted that where possible, this should be left to the market, within the parameters of competition law and open standards. Authorities should encourage moves to alternative platforms only where markets clearly fail, and where it is objectively undisputable that the alternative platform is superior from a public interest perspective. In that context, it is not clear what legal basis RAND proposes the Commission should rely upon if not on the competition rules and a public procurement policy favouring open standards. ${ }^{64}$

Second, it is true that ex post remedies may not always be effective and anticompetitive behaviour may not always be detected or prohibited ex ante, but where it can, why not use competition law? As the guardian of the Treaty, the Commission should not be allowed to disregard distortions in a sector as important as the Internet. Lessons can be learned from past failures in remedies - as the Commission did in Microsoft, where the 2009 Browser Choice Commitment and Interoperability Undertaking are much more promising than the remedies in the 2004 Decision. Indeed, enforcement action can be a remedy in itself where it deters future violations by the firm or standards body in question, and by others. And in those cases where remedies and anticompetitive behaviour cannot be detected or prohibited ex ante, how could the Commission possibly devise a consumer protection policy that is more effective than competition law? Even if the Commission has a crystal ball and is able to define appropriate ex ante rules, these could more easily and more quickly be set out in the Commission's Guidelines on Horizontal Agreements and applied in cases. ${ }^{65}$ The most effective solution, it is submitted, is to define "open standards" as a condition for

63 Jonathan Cave kindly explained this and pointed out that Ofcom has undertaken this in its efforts to overcome lock-in among ADSL subscribers unable to obtain MAC codes or even to make authoritative and meaningful comparisons of Quality of Service and related attributes of IPSs' offerings.

64 See also European Commission, White Paper, Modernising ICT Standardisation in the EU - The Way Forward, $\operatorname{COM}(2009) 324$ final, July 3, 2009, p. 6-7. The requirement in procurement rules, that requests for proposals should refer to European standards where available, serves to ensure maximum consumer choice and dynamic competition, and these goals could be subverted if closed or proprietary standards qualified for preferential treatment under procurement rules.

65 It is unclear whether there is a legal basis in consumer protection provisions of the Treaties, and adoption and implementation of appropriate instruments will take years and be controversial, if it can ever be achieved. It may be possible to amend the Standardization Directive to insist on open standards for European standard setting (Directive 98/34/EC of the European Parliament and of the Council of 22 June 1998, laying down a procedure for the provision of information in the field of technical standards and regulations and of rules on Information Society services (OJ L 204 of 21.07.1998), as amended by Directive 98/48/EC (OJ L 217 of 05.08.1998), but even that will be subject to controversy and intense lobbying by firms that benefit from hold-up practices. Fostering open standard setting under Articles 101(3) and 102 TFEU and the Guidelines for Horizontal Agreements seems the most efficient solution, certainly in the short term. 
exemption of standards agreements under Articles 101(3) and 102 TFEU. This in fact provides some kind of ex ante remedy: if these "open standards" conditions are applied during the standards process, the outcome of the standards process is likely to be consistent with competition policy, obviating the need for ex post intervention.

Third, it should be recalled that the conception and growth of the Internet was government-funded and took place in a public sector and university environment. As the private sector takes over, and the risk of lock and hold-up emerges, it becomes more, not less, important to apply the principles of competition law.

Competition law has the merit of providing a flexible framework that does not require adoption of additional rules. After the closure of the Qualcomm case without action in the EU (although action was taken in Japan and Korea and some settlements were reached), some might question whether competition law can be used to prevent consumer exploitation. Lemley argues that it is even undesirable, and that antitrust is " a back-stop that's going to apply only if private efforts in SSOs and IP law have already failed us." ${ }^{\circ 6}$ The problem is that private efforts can be blocked by firms that benefit from hold-ups. Experience suggests that this would likely prevent standards organizations - working by consensus - from modifying their IPR Policies meaningfully. At best, this will take a long time, and at worst, it will never happen satisfactorily. The same firms also argue in court that FRAND promises are unenforceable in contract or even under promissory estoppel principles, and are merely a promise to negotiate. Amendments to IP law are not much more promising either. Getting twenty-seven Member States to change their IP laws to prevent hold-ups is probably a pipe-dream. Member States judges are equally unlikely to change the law, since they are much less policy-oriented than their US brethren. Antitrust law seems to be the only available tool to achieve a focused, timely, EU-wide solution. Regulation and IPR laws are blunt instruments with "one-size-fits-all" impact, whereas competition law allows intervention with surgical precision, permits remedies appropriate to address the precise problem and strike the right balance in the specific circumstances of the case, and creates flexible precedent that can be adjusted to new fact patterns.

More important, the public policy concerns under US law that advocate against use of antitrust law (the heavy burden of treble damages, the extraordinary high cost of defense as a result of extensive discovery, the risk of spurious litigation driven by contingency fee arrangements and class actions tried before juries, the need to prove intent) are absent or much less of a concern in the EU. Moreover, contrary to Section 2 of the US Sherman Act, Articles 102(a) and (c) TFEU prohibits excessive pricing and unjustified discrimination restricting downstream competition, and neither the courts nor the Commission are at liberty to ignore the legislator's intent in that respect $-a$ fortiori in the context of a FRAND promise.

This is not to suggest that the Commission should initiate competition law proceedings under Articles 101 or 102 TFEU against standards bodies with inadequate procedures and poor IPR Policies, on the basis of an argument that standards organizations with inadequate rules do not qualify for exemption under Article 101(3) TFEU. Nor should the Commission take away the special status of CEN, CENELEC or ETSI because their policies are deficient. Taking action

66 See M. Lemley, “Ten Things to Do About Patent Holdup of Standards (and One Not to)", (2007) 48 B.C. L. Rev. 149, $151-55$. 
against standards bodies, or prohibiting individual standards, is in many cases impractical, such as with respect to international organizations like ISO and IEEE. ${ }^{67}$ In all cases it means punishing the victim rather than the perpetrators of standards manipulation or hold-ups. It is better to take firm action against companies that distort standards practices, impose excessive royalties, or impose restrictive licensing terms.

Fourth, the RAND Report mentions that there may be no counterfactual evidence to demonstrate that alternatives are viable if lock-in is widespread. But competition law provides an elegant way out. In Rambus, for instance, there was evidence that Rambus took steps to conceal its patent and patent applications. Had it really thought that its technology was better than the available alternatives that JEDEC (the standards body) considered, why did it take such steps? By concealing the information, it prevented the counterfactual from materializing, and it should bear the consequences for that: In cases where IPR owners conceal evidence of IPRs, or impose confidentiality clauses preventing licensees from warning standards bodies that royalties are too high or terms are exclusionary, the burden of proof should be switched to the IPR owner to show that no viable alternative existed for their technology and that the standards body would have included their IPR anyway without a FRAND licensing obligation. Case-law provides precedent for such a switch in the burden of proof. ${ }^{68}$

A final comment concerns the statement that "many of the specific activities that firms might use for predatory purposes (e.g. proprietary standards, low "penetration" pricing, etc.) are also essential in order to attract complementary content and services to Internet platforms capable of providing effective competition." Of course, low pricing or even giving away products or services may be legitimate in order to foster a network effect or attract business in a two-sided market. Similarly, building products based on proprietary technology like Apple's iPod and iTunes is a legitimate business model. But using closed standards is not "essential" to attract complementary content or services - they are at best neutral in attracting complementary products, and tend to limit competition from substitutes.

To conclude: The RAND Report should be commended for recognizing the importance of open standards, and the criteria suggested above (including the conclusion that software-to-software interoperability standards should be patent or royalty-free where alternative revenue models exist) fit well within this framework. The paragraph on p. 132 should not be relied upon to throw out competition policy as a tool to maintain an open Internet. The comment that "conventional" antitrust policy is less effective, is better understood as a call for application of more innovative competition policy to strengthen open standards and foster consumer welfare and consumer choice, which are the objectives of competition policy. This is also consistent with comments elsewhere in the RAND Report (p. 100, emphasis in original):

"One key element is the importance of market competition in motivating and funding the development of innovations and in determining their availability, affordability and the resulting impacts on societal objectives. As a result, ...effective competition policy remains essential. This raises new challenges for existing (technical and economic) regulators in relation to IPR,

67 It is also impractical with respect to ETSI, whose IPR Policy was, after all, granted negative clearance. See OJ 1995 No C 76, p. 5, and 25th Report on Competition Policy 1995, pp. 131-132.

68 Cf Case C-395/87 Ministère Public v Tournier [1989] ECR 2521, [1991] 4 CMLR 248, para 38. 
bundling and the treatment of joint ventures. More profoundly, it can change the synergistic relation that has traditionally existed between competition and consumer protection policies. To avoid capture, unjustified market distortion or an inappropriate balance of efficiency and innovation, it is necessary to ensure that competition policy promotes the efficiency benefits anticipated from competition rather than competition for its own sake."

The EU may consider legislation that lays out a common set of rules for "fair play" in standards negotiation. But while regulation and IPR laws are blunt instruments, competition law properly and energetically applied allows intervention with surgical precision, permits remedies appropriate to address the precise problem and strike the right balance in the specific circumstances of the case, and creates flexible precedent that can be adjusted to new fact patterns. The Commission showed this when it negotiated a browser choice screen for Windows: Competition in browsers creates opportunities for alternative browsers that comply with open standards such as HTLM5, and if enough users exercise that choice, developers will have incentives to use those open standards as well, keeping the Internet open. This remedy, therefore, allows the market to speak. Let's hope that the proposed revision of the Guidelines on Horizontal Agreements will reflect this open standards approach, that Commissioner Almunia will apply it, and that Commissioner Kroes will integrate competition policy when setting the Digital Agenda in her new position.

\section{About the authors}

Maurits Dolmans is a partner at Cleary Gottlieb Steen \& Hamilton LLP, London and Brussels. The author has been and still si involved in various cases relating to standards, IPR and competition, including most recently on the side of complainants in Microsoft, Rambus, IPCom, and Qualcomm, and on the side of defendants in HD-DVD/Blu-ray and pending other matters, and has acted as outside counsel for standards bodies such as DVB and ETSI. This paper, however, reflects his personal views in an evolving debate, and do not bind the firm or its clients. The author thanks his colleagues Thomas Graf and Lars-Peter Rudolf, Jonathan Cave of Warwick University, and Hal Varian of UC Berkeley for their insightful comments and critical review.

Carlo Piana is an Italian IT lawyer based in Milan as well as a Free Software and digital liberties advocate. Since 2004 he provides consulting to the FSFE and assists the same in battles for competition and open standards. He has represented FSFE and the Samba Team in the antitrust European litigation for obtaining the full interoperability information of the Windows networking interfaces. He is a member of the Editorial Committee of this Review and a strong believer in Free Software and Digital Human Rights. 


\section{Licence and Attribution}

This paper was first published in Published in:

Concurrences $N^{\circ} 1-2010, n^{\circ} 30204, p p .13-38$

http://www.concurrences.com/

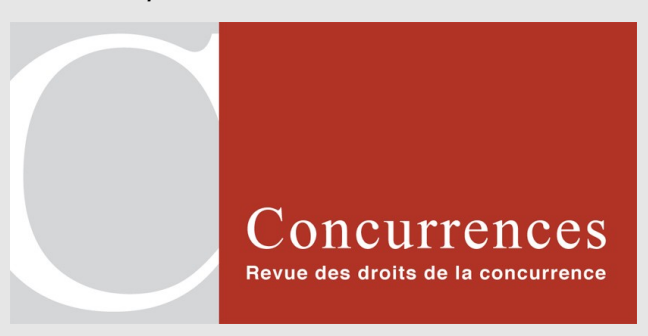

It was republished courtesy of the Review Concurrences in the International Free and Open Source Software Law Review, Volume 2, Issue 2 (December 2010). It originally appeared online at http://www.ifosslr.org. The introduction is a work of Carlo Piana, approved by the Author.

This article should be cited as follows:

Dolmans, Marurits (2010) 'A Tale of Two Tragedies - A plea for open standards, and some comments on the RAND report', IFOSS L. Rev., 2(2), pp 115 - 138 DOI: $\underline{10.5033 / \text { ifosslr.v2i2.46 }}$

Copyright (C) 2010 Maurits Dolmans.

This article is licensed under a Creative Commons UK (England and Wales) 2.0 licence, no derivative works, attribution, CC-BY-ND.

As a special exception, the author expressly permits faithful translations of the entire document into any language, provided that the resulting translation (which may include an attribution to the translator) is shared alike. This paragraph is part of the paper, and must be included when copying or translating the paper.

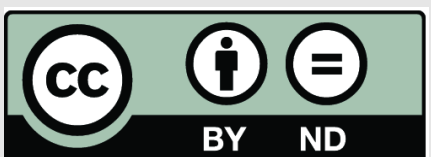


